\title{
The Distribution Frequency of Interferon-Gamma Receptor 1 Gene Polymorphisms in Interferon- $\gamma$ Release Assay-Positive Patients
}

\author{
Changguo Chen, ${ }^{1}$ Lei Chen, ${ }^{1}$ Changwei Chen, ${ }^{2}$ Qiuyuan Chen, ${ }^{1}$ Qiangyuan Zhao, ${ }^{1}$ and \\ Youyou Dong ${ }^{1}$ \\ ${ }^{1}$ Department of Clinical Laboratory, The Navy General Hospital, No. 6 Fucheng Road, Beijing 100037, China \\ ${ }^{2}$ Department of Pathology, Donghua Hospital Affiliated to Zhongshan University, No. 1 Dongcheng Road, Dongguan, \\ Guangdong 523110, China \\ Correspondence should be addressed to Changguo Chen; 1234_chen@sina.com
}

Received 11 September 2017; Revised 1 October 2017; Accepted 8 October 2017; Published 25 October 2017

Academic Editor: Marco E. M. Peluso

Copyright ( 92017 Changguo Chen et al. This is an open access article distributed under the Creative Commons Attribution License, which permits unrestricted use, distribution, and reproduction in any medium, provided the original work is properly cited.

\begin{abstract}
Tuberculosis is caused by mycobacterium, a potentially fatal infectious bacterium. In recent years, TB cases increased in the whole world. WHO statistics data shows that the world's annual tuberculosis incidence was $8 \sim 10$ million with about 3 million deaths. Several studies have shown that susceptibility to tuberculosis may be associated with IFNGR1 gene polymorphisms. Here, we report the distribution frequency of IFNGR1 gene polymorphisms in 103 cases of IGA-negative patients and 100 cases of IGA-positive patients from China by sequencing the IFNGR1 proximal $750 \mathrm{bp}$ promoter region. We found a total of 5 types of site mutations: $-611(\mathrm{G} / \mathrm{A}),-56(\mathrm{~T} / \mathrm{C}),-255(\mathrm{C} / \mathrm{T}),-359(\mathrm{~T} / \mathrm{C})$, and $-72(\mathrm{C} / \mathrm{T})$. The two main types of gene polymorphisms among the IGA-negative and IGA-positive groups were $-611(\mathrm{G} / \mathrm{A})$, with mutation rates of $88.3 \%$ and $78.4 \%$, respectively, and $-56(\mathrm{~T} / \mathrm{C})$, with mutation rates of $84.5 \%$ and $83.8 \%$, respectively, which had no statistical significance, and there was no correlation with the incidence of tuberculosis.
\end{abstract}

\section{Background}

As a common infectious disease, the prevalence of tuberculosis (TB) has been increasing around the globe, especially in Asia and Africa, and is influenced by multiple factors [1-3]. WHO statistics data demonstrate that the world's annual tuberculosis incidence was $8 \sim 10$ million and approximately 3 million people died of tuberculosis, which is the largest number of deaths caused by a single infectious disease [4-6]. In the past 10 years, the incidence of bacteriologically positive pulmonary tuberculosis patients in our country was less than $30 \%$, as evidenced from the results of the digital epidemiological survey conducted every year $[4,5]$. China is one of the 22 countries with the highest burden of $\mathrm{TB}$ in the world, ranking second in the number of $\mathrm{TB}$ patients, after India [7-10]. In addition to environmental factors, an increasing number of studies and reviews indicate that host genetic factors play an important role in susceptibility to tuberculosis $[6,11-13]$.

The IFN- $\gamma$ release assay (IGRA) is an in vitro release enzyme-linked immunosorbent assay used to measure specific antigen-mediated cellular immune responses. A Mycobacterium tuberculosis-specific recombinant antigen was used to stimulate specific T lymphocytes and make them proliferate. The plasma levels of IFN- $\gamma$ released by the sensitized $\mathrm{T}$ cells in the whole blood, after being stimulated by the MTB-specific antigen, were detected to determine Mycobacterium tuberculosis infection. IGRAs can offset the drawbacks of tuberculin skin testing [14-17]. At present, several countries routinely diagnose MTB latent infections (latent tuberculosis infection (LTBI)), which has a positive significant effect on tuberculosis control.

IFN- $\gamma$ plays an important role in innate and adaptive immunity and was first discovered in 1965; in addition, 
TABLE 1

\begin{tabular}{ccclc}
\hline$n$ & P-N & T-N & Results & Result interpretation \\
\hline & Any value & $\geq 14$ and $\geq \mathrm{N} / 4$ & Positive & $\begin{array}{c}\text { Mycobacterium tuberculosis infection (tuberculosis activity stage infection, } \\
\text { latent infection, or positive infection) }\end{array}$ \\
$\leq 400$ & $\geq 20$ & $<14$ & Negative & Uninfected Mycobacterium tuberculosis \\
& $\geq 20$ & $\geq 14$ 但 $<\mathrm{N} / 4$ & Negative & \\
& $<20$ & $<14$ & Not sure & \\
& $<20$ & $\geq 14$ 但 $<\mathrm{N} / 4$ & Not sure & It is not certain whether the Mycobacterium tuberculosis infection is infected \\
& Any value & Any value & Not sure & \\
\hline
\end{tabular}

it belongs to the type II interferon. IFNGR1 is the IFN- $\gamma$ receptor $\alpha$ chain; it is expressed on the surface of all cells except red blood cells and is necessary for the binding of IFN- $\gamma$ and its signal transduction $[18,19]$. The SNP of the IFNGR1 promoter has been associated with various diseases. Several studies have demonstrated that susceptibility to tuberculosis may be associated with IFNGR1 gene polymorphisms [20-22]. Thus, the present study aimed to examine the distribution frequency of interferon-gamma $($ IFN- $\gamma$ ) receptor 1 (IFNGR1) gene polymorphisms in patients with positive interferon- $\gamma$ release assays.

\section{Methods}

2.1. General Data. A total of 203 hospitalized patients who were suspected of tuberculosis infection by clinicians at the Navy General Hospital from March 2015 to April 2016 were enrolled in the research group, including 103 cases of IFN- $\gamma$ release assay result-negative patients and 100 cases of IFN- $\gamma$ release assay result-positive patients. The patients' basic information, results of tuberculin skin testing and results of the Zeihl-Neelsen acid-fast stain test, were collected from the hospital's digital medical record system. Overall, there were 136 males within the age range of 19 to 93 years and 67 females within the age range of 23 to 87 years.

2.2. Detecting Plasma Levels of IFN- $\gamma$. Venous puncture was used to collect the whole blood samples, no less than $4 \mathrm{~mL}$. The blood samples were gently mixed evenly $3 \sim 5$ times and then divided into three groups of culture tubes: $\mathrm{N}$ (control), $\mathrm{T}$ (test), and $\mathrm{P}$ (positive control); $1 \mathrm{~mL} /$ tube. The cultivation pipes were gently mixed upside down 5 times and incubated for $22 \pm 2$ hours at $37^{\circ} \mathrm{C}$. Following incubation, the culture tubes were centrifuged for 10 minutes at $3000 \sim 5000 \mathrm{rpm} / \mathrm{min}$. Fifty microliters of supernatant was used to detect IFN- $\gamma$ levels by ELISA, and the cutoff value was $>14 \mathrm{pg} / \mathrm{mL}$, and interpretation of the results is presented in Table 1.

2.3. Extraction of Genomic DNA. Total genomic DNA of leukocytes was extracted from $0.2 \mathrm{~mL}$ of peripheral blood using the Whole Blood DNA Extraction Kit (Tiangen Biotech Co. Ltd., Beijing, China), according to the manufacturer's instructions. The genomic DNA extracted was dissolved in
TABLE 2: Characteristics of 100 IGA-positive patients.

\begin{tabular}{lc}
\hline Characteristics & Number \\
\hline Patients & 100 \\
Male/female & $66 / 34$ \\
Age range & $19-93 / 24-87$ \\
Pulmonary disease & 55 \\
Purely IGA positive & 82 \\
Positive evidence of other TB-related indicators & \\
IGA and tuberculin skin testing positive & 15 \\
IGA and the Zeihl-Neelsen acid-fast stain positive & 1 \\
IGA, tuberculin skin testing, and the Zeihl-Neelsen & 2 \\
acid-fast stain positive & \\
\hline
\end{tabular}

$0.1 \mathrm{x}$ TE buffer (10 mM Tris $-1 \mathrm{mM}$ EDTA, $\mathrm{pH} 8.0)$ and stored at $-20^{\circ} \mathrm{C}$.

2.4. Amplification and Sequencing of IFNGR1 Proximal Promoter PCR. Primer premier 5.0 software was used to design primers for amplification of $750 \mathrm{bp}$ proximal fragments of IFNGR1; forward 5'- CAGGTGAGATCATT AGACATTCGC- $3^{\prime}$ and reverse $5^{\prime}$ - GCTGCTACCGA CGGTCGCTG -3 '. In each $0.2 \mathrm{~mL}$ PCR reaction tube, $1 \mu \mathrm{L}$ of genomic DNA (100 ng/mL), $1 \mu \mathrm{L}$ of each primer, $10 \mu \mathrm{L}$ of $2 \mathrm{X}$ PrimeTaq Premix (Tiangen Biotech, Co., Ltd, Beijing, China), and the appropriate amount of $\mathrm{ddH} 2 \mathrm{O}$ were added. The PCR cycling conditions were as follows: initial denaturation at $95^{\circ} \mathrm{C}$ for $5 \mathrm{~min}$ followed by 30 cycles for $30 \mathrm{~s}$ at $94^{\circ} \mathrm{C}$, annealing at $58^{\circ} \mathrm{C}$ for $30 \mathrm{~s}$, and extension at $72^{\circ} \mathrm{C}$ for $45 \mathrm{~s}$, with a final extension at $72^{\circ} \mathrm{C}$ for $7 \mathrm{~min}$. The PCR products were run on $1.0 \%$ agarose gels containing $0.5 \%$ GoldView $^{\mathrm{TM}}$ and observed under UV light. The genotyping of the IFNGR1 sequence was done by Sanger sequencing (Aoke DINGSHENG Biotechnology Co. Ltd., Beijing, China).

2.5. Statistical Analysis. Analysis of data was done using the SPSS 19.0 software. Differences between variables were evaluated by Fisher's exact test according to the data. The associations between genotypes and IFN- $\gamma$ levels were calculated using the Cochran-Armitage test for trend. $P$ values less than 0.05 were considered statistically significant. 

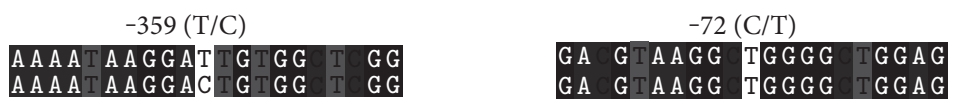

Figure 1

TABLE 3: Mutation of IFNGR1 promoter site in different IFN- $\gamma$ l levels $(n(\%))$.

\begin{tabular}{|c|c|c|c|c|c|c|}
\hline IFN- $\gamma$ level & $n$ & $-611(\mathrm{G} / \mathrm{A})$ & $-56(\mathrm{~T} / \mathrm{C})$ & $-255(\mathrm{C} / \mathrm{T})$ & $-359(\mathrm{~T} / \mathrm{C})$ & $-72(\mathrm{C} / \mathrm{T})$ \\
\hline IFN- $\gamma>400 \mathrm{pg} / \mathrm{mL}$ & 18 & $16(89 \%)$ & $16(89 \%)$ & $3(11 \%)$ & $1(0.05 \%)$ & $0(0 \%)$ \\
\hline $200 \mathrm{pg} / \mathrm{mL}<\mathrm{IFN}-\gamma<400 \mathrm{pg} / \mathrm{mL}$ & 28 & $21(75 \%)$ & $25(89 \%)$ & $0(0 \%)$ & $0(0 \%)$ & $0(0 \%)$ \\
\hline $14 \mathrm{pg} / \mathrm{mL}<$ IFN $-\gamma<200 \mathrm{pg} / \mathrm{mL}$ & 54 & $41(76 \%)$ & $42(78 \%)$ & $4(0.07 \%)$ & $0(0 \%)$ & $1(0.02 \%)$ \\
\hline IFN- $\gamma<14 \mathrm{pg} / \mathrm{mL}$ & 103 & $91(88.3 \%)$ & $87(84.5)$ & $2(1.9 \%)$ & $0(0 \%)$ & $0(0 \%)$ \\
\hline
\end{tabular}

\section{Results}

3.1. Characteristics of Patients. The study consisted of 103 IGA-negative patients ( 70 males aged 23 to 88 years and 33 females aged 23 to 90 years), and pulmonary disease was detected in 76 cases of 100 IGA-positive patients (66 males aged 19 to 93 years and 34 females aged 24 to 87 years). Pulmonary disease was detected in 55 cases, of which 2 cases were diagnosed as tuberculosis. There were 82 cases that were purely IGA-positive and 18 cases of positive evidence of other TB-related indicators; 15 cases were positive for IGA and tuberculin skin testing; 1 case was positive for IGA and the Zeihl-Neelsen acid-fast stain test; 2 cases were positive for IGA, Tuberculin skin testing and the Zeihl-Neelsen acid-fast stain test (Table 2). There was no significant difference between the groups with respect to sex and age $(P>0.05)$.

3.2. Mutations Obtained by BioEdit Sequence Alignment. Sequence information was obtained by first generation sequencing technology. In the IGA-negative group, the $-611(\mathrm{G} / \mathrm{A})$ mutation rate was $88.3 \%$, and the -56 (T/C) mutation rate was $84.5 \%(-611(\mathrm{G} / \mathrm{A}),-56(\mathrm{~T} / \mathrm{C})$ : 79 cases; -611 (G/A), -56 (T/T): 14 cases; -611 (G/G), -56 (T/C): 9 cases; and $-611(\mathrm{G} / \mathrm{G}),-56(\mathrm{~T} / \mathrm{T}): 3$ cases$)$. In the IGApositive group, the $-611(\mathrm{G} / \mathrm{A})$ mutation rate was $78 \%$ and the $-56(\mathrm{~T} / \mathrm{C})$ mutation rate was $83 \%(-611(\mathrm{G} / \mathrm{A})$, -56 (T/C): 70 cases; -611 (G/A), $-56(\mathrm{~T} / \mathrm{T}): 8$ cases; -611 (G/G), -56 (T/C): 13 cases; and $-611(\mathrm{G} / \mathrm{G}),-56(\mathrm{~T} / \mathrm{T}): 9$ cases). Other mutations were also observed, such as -255 $(\mathrm{C} / \mathrm{T}),-359(\mathrm{~T} / \mathrm{C})$, and $-72(\mathrm{C} / \mathrm{T})$ (Figure 1$)$.

\subsection{Distribution of the IFNGR1 Promoter Mutation in} Different Plasma Levels of IFN- $\gamma$. According to the plasma levels of IFN- $\gamma$, the subjects were divided into four groups: IFN- $\gamma>400 \mathrm{pg} / \mathrm{mL}, 200 \mathrm{pg} / \mathrm{mL}<$ IFN- $\gamma<400 \mathrm{pg} / \mathrm{mL}$, IFN$\gamma<200 \mathrm{pg} / \mathrm{mL}$, and IFN $-\gamma<14 \mathrm{pg} / \mathrm{mL}$. The mutations in the IFNGR1 gene were observed at different loci corresponding to different IFN- $\gamma$ levels, and the mutations $-611(\mathrm{G} / \mathrm{A})$ and $-56(\mathrm{~T} / \mathrm{C})$ were the highest among the gene polymorphisms of the IFNGR1 promoter but were uncorrelated with the plasma levels of IFN- $\gamma, P>0.005$ (Table 3).

\section{Discussion}

Tuberculosis, which is an infectious disease and remains a major public health problem as well as a leading cause of morbidity, has plagued human beings for thousands of years $[1,6,23]$. In recent years, the incidences and mortality of tuberculosis have been rising. Infection with Mycobacterium tuberculosis is related not only to the external environment but also to the impact of genetic factors on the phenotypic variation and immune responses in the population infected with TB [24-27]. Although the evidence for a human genetic component in susceptibility to TB is incontrovertible, some genetic variation in cytokine-associated genes, including IFNGR1 and IFNGR2, has previously been found to be important in other viral/host-mediated immune responses in TB $[28,29]$. IFNGR1, as a key molecule of the IFN- $\gamma$ signalling pathway, was believed to play a key role in the pathogenesis of TB. People with hereditary IFNGR1 disorder are more susceptible to TB [30-32]. Shin et al. suggested that certain genetic variants in IFNGR genes may be associated with TB development [33]; Lü et al. demonstrated that rs2234711, rs1327475, and rs7749390 polymorphisms of the IFNGR1 gene were significantly associated with the altered risks of TB [21]. IFNGR1 proximal promoter gene polymorphisms also were believed that they were positively associated with an increased susceptibility to Mycobacterium leprae [34] and that IFNGR1-56 T/C polymorphism was a "biomarker" for identifying populations at higher risk of Nontuberculous mycobacteria infection [35]. However, Bulat-Kardum et al. noted that there was no significant correlation between the susceptibility of tuberculosis with the IFNGR1 proximal promoter $-611 \mathrm{G} / \mathrm{A}$ and $-56 \mathrm{~T} / \mathrm{C}$ gene polymorphisms [36]. Furthermore, Rosenzweig et al. suggested that the $-611 \mathrm{G} / \mathrm{A}$ and $-56 \mathrm{~T} / \mathrm{C}$ gene polymorphisms were not associated with increased mycobacterial susceptibility [37]. The meta-analysis of Wang et al. believed that 
IFNGR1 -56C/T is possibly associated with increased TB risk in Africans, but not in Asians or Caucasians [38].

In the present study, we screened 103 patients of Chinese Han nationality who were IGA negative and 100 patients who were IGA positive. By sequencing the IFNGR1 promoter, we found a total of 5 types of site mutations: -611 (G/A), $-56(\mathrm{~T} / \mathrm{C}),-255(\mathrm{C} / \mathrm{T}),-359(\mathrm{~T} / \mathrm{C})$, and $-72(\mathrm{C} / \mathrm{T})$. The two main types of gene polymorphisms among the IGA-negative and IGA-positive groups were -611 (G/A), with mutation rates of $88.3 \%$ and $78.4 \%$, respectively, and $-56(\mathrm{~T} / \mathrm{C})$, with mutation rates of $84.5 \%$ and $83.8 \%$, respectively, which had no statistical significance. There were 9 cases with $-255(\mathrm{C} / \mathrm{T})$ mutation, 1 case with -359 (T/C) mutation, and 1 case with $-72(\mathrm{C} / \mathrm{T})$ mutation. Although the mutation rates were low, their potential clinical value needs to be further verified. Because we are not a hospital specializing in treating tuberculosis, the number of confirmed cases was relatively small. In 4 cases, the patients were Zeihl-Neelsen acid-fast stain positive, 1 patient had the -611 (G/A) and $-56(\mathrm{~T} / \mathrm{C})$ mutations, and 3 patients had the $-56(\mathrm{~T} / \mathrm{C})$ mutation. Of the 55 patients with pulmonary disease, the -611 (G/A) mutation was observed in 52 patients and the -56 (T/C) mutation was observed in 48 patients.

There are some limitations to our study, we observed that the $-611(\mathrm{G} / \mathrm{A})$ and $-56(\mathrm{~T} / \mathrm{C})$ mutations in IGA-positive patients have no difference compared with the IGA-negative patients. Therefore, we believe that there is not a certain correlation between the incidence of the -611 (G/A) and -56 (T/C) mutations and TB.

\section{Conflicts of Interest}

The authors declare that they have no competing interests.

\section{Acknowledgments}

This work was supported by the National Natural Science Foundation (no. 81401311) and the Capital Characteristic Clinical Application Research (Wu Jieping Foundation no. Z141107006614009). This work was also supported by the Navy General Hospital Innovation Cultivation Foundation (no. CXPY201412).

\section{References}

[1] P. L. Lin and J. L. Flynn, "Understanding latent tuberculosis: a moving target," The Journal of Immunology, vol. 185, no. 1, pp. 15-22, 2010.

[2] T. Kondratieva, T. Azhikina, B. Nikonenko, A. Kaprelyants, and A. Apt, "Latent tuberculosis infection: what we know about its genetic control?," Tuberculosis, vol. 94, no. 5, pp. 462-468, 2014.

[3] M. Raviglione and G. Sulis, "Tuberculosis 2015: burden, challenges and strategy for control and elimination," Infectious Disease Reports, vol. 8, no. 2, p. 6570, 2016.

[4] M. Mjid, J. Cherif, N. Ben Salah et al., "Epidemiology of tuberculosis," Revue de Pneumologie Clinique, vol. 71, no. 2-3, pp. 67-72, 2015.

[5] A. Zumla, A. George, V. Sharma, N. Herbert, and Baroness Masham of Ilton, "WHO's 2013 global report on tuberculosis: successes, threats, and opportunities," The Lancet, vol. 382, no. 9907, pp. 1765-1767, 2013.

[6] A. El Kamel, S. Joobeur, N. Skhiri, S. Cheikh Mhamed, H. Mribah, and N. Rouatbi, "Fight against tuberculosis in the world," Revue de Pneumologie Clinique, vol. 71, no. 2-3, pp. 181-187, 2015.

[7] D. Li, J. L. Wang, B. Y. Ji et al., "Persistently high prevalence of primary resistance and multidrug resistance of tuberculosis in Heilongiiang province, China," BMC Infectious Diseases, vol. 16, no. 1, p. 516, 2016.

[8] Z. Xu, T. Xiao, Y. Li, K. Yang, Y. Tang, and L. Bai, “Reasons for non-enrollment in treatment among multi-drug resistant tuberculosis patients in Hunan province, China," PLoS One, vol. 12, no. 1, article e0170718, 2017.

[9] P. Glaziou, D. Falzon, K. Floyd, and M. Raviglione, "Global epidemiology of tuberculosis," Seminars in Respiratory and Critical Care Medicine, vol. 34, no. 1, pp. 3-16, 2013.

[10] X. Yang, Y. Yuan, Y. Pang et al., "The burden of MDR/XDR tuberculosis in coastal plains population of China," PLoS One, vol. 10, no. 2, article e0117361, 2015.

[11] H. Zhang, X. Li, H. Xin et al., "Association of body mass index with the tuberculosis infection: a population-based study among 17796 adults in rural China," Scientific Reports, vol. 7, article 41933, 2017.

[12] M. H. Haverkamp, J. T. van Dissel, and S. M. Holland, "Human host genetic factors in nontuberculous mycobacterial infection: lessons from single gene disorders affecting innate and adaptive immunity and lessons from molecular defects in interferon- $\gamma$-dependent signaling," Microbes and Infection, vol. 8, no. 4, pp. 1157-1166, 2006.

[13] H. Q. Qu, S. P. Fisher-Hoch, and J. B. McCormick, "Molecular immunity to mycobacteria: knowledge from the mutation and phenotype spectrum analysis of Mendelian susceptibility to mycobacterial diseases," International Journal of Infectious Diseases, vol. 15, no. 5, pp. e305-e313, 2011.

[14] A. Nienhaus, A. Schablon, J. T. Costa, and R. Diel, "Systematic review of cost and cost-effectiveness of different TB-screening strategies," BMC Health Services Research, vol. 11, p. 247, 2011.

[15] M. L. de Souza-Galvao, I. Latorre, N. Altet-Gomez et al., "Correlation between tuberculin skin test and IGRAs with risk factors for the spread of infection in close contacts with sputum smear positive in pulmonary tuberculosis," $B M C$ Infectious Diseases, vol. 14, no. 1, p. 258, 2014.

[16] R. Diel, D. Goletti, G. Ferrara et al., "Interferon- $\gamma$ release assays for the diagnosis of latent Mycobacterium tuberculosis infection: a systematic review and meta-analysis," The European Respiratory Journal, vol. 37, no. 1, pp. 88-99, 2011.

[17] R. Diel, R. Loddenkemper, and A. Nienhaus, "Predictive value of interferon- $\gamma$ release assays and tuberculin skin testing for progression from latent TB infection to disease state," Chest, vol. 142, no. 1, pp. 63-75, 2012.

[18] C. Chen, L. Guo, M. Shi et al., "Modulation of IFN- $\gamma$ receptor 1 expression by AP- $2 \alpha$ influences IFN- $\gamma$ sensitivity of cancer cells," The American Journal of Pathology, vol. 180, no. 2, pp. 661-671, 2012.

[19] C. M. Ahmed and H. M. Johnson, "IFN- $\gamma$ and its receptor subunit IFNGR1 are recruited to the IFN- $\gamma$-activated sequence element at the promoter site of IFN- $\gamma$-activated genes: evidence of transactivational activity in IFNGR1," The Journal of Immunology, vol. 177, no. 1, pp. 315-321, 2006. 
[20] G. S. Cooke, S. J. Campbell, J. Sillah et al., "Polymorphism within the interferon- $\gamma /$ receptor complex is associated with pulmonary tuberculosis," American Journal of Respiratory and Critical Care Medicine, vol. 174, no. 3, pp. 339-343, 2006.

[21] J. Lü, H. Pan, Y. Chen et al., "Genetic polymorphisms of IFNG and IFNGR1 in association with the risk of pulmonary tuberculosis," Gene, vol. 543, no. 1, pp. 140-144, 2014.

[22] M. Hashemi, E. Eskandari-Nasab, A. Moazeni-Roodi, M. Naderi, B. Sharifi-Mood, and M. Taheri, "Association of CTSZ rs34069356 and MC3R rs6127698 gene polymorphisms with pulmonary tuberculosis," The International Journal of Tuberculosis and Lung Disease, vol. 17, no. 9, pp. 1224-1228, 2013.

[23] I. Onozaki and M. Raviglione, "Stopping tuberculosis in the 21st century: goals and strategies," Respirology, vol. 15, no. 1, pp. 32-43, 2010.

[24] P. D. van Helden, M. Möller, C. Babb et al., "TB epidemiology and human genetics," Novartis Foundation Symposia, vol. 279, pp. 17-31, 2006.

[25] K. Aggelou, E. K. Siapati, I. Gerogianni et al., "The -938C >A polymorphism in MYD88 is associated with susceptibility to tuberculosis: a pilot study," Disease Markers, vol. 2016, Article ID 4961086, 5 pages, 2016.

[26] E. Ghamari, P. Farnia, S. Saif et al., "Susceptibility to pulmonary tuberculosis: host genetic deficiency in tumor necrosis factor alpha (TNF- $\alpha$ ) gene and tumor necrosis factor receptor 2 (TNFR2)," International Journal of Mycobacteriology, vol. 5, Supplement 1, pp. S136-S137, 2016.

[27] O. Caceres, N. Rastogi, C. Bartra et al., "Characterization of the genetic diversity of extensively-drug resistant Mycobacterium tuberculosis clinical isolates from pulmonary tuberculosis patients in Peru," PLoS One, vol. 9, no. 12, article e112789, 2014.

[28] E. Catherinot, C. Fieschi, J. Feinberg, J. L. Casanova, and L. J. Couderc, "Genetic susceptibility to mycobacterial disease: Mendelian disorders of the interleukin-12 - interferon-axis," Revue des Maladies Respiratoires, vol. 22, 5, Part 1, pp. 767-776, 2005.

[29] P. Farnia, J. Ghanavi, P. Tabasri, S. Saif, and A. A. Velayati, "The importance of single nucleotide polymorphisms in interferon gamma receptor-1 gene in pulmonary patients infected with rapid grower mycobacterium," International Journal of Mycobacteriology, vol. 5, Supplement 1, pp. S210-S211, 2016.

[30] W. T. Quispel, J. A. Stegehuis-Kamp, S. J. Santos et al., "Intact IFN- $\gamma \mathrm{R} 1$ expression and function distinguishes Langerhans cell histiocytosis from Mendelian susceptibility to mycobacterial disease," Journal of Clinical Immunology, vol. 34, no. 1, pp. 84-93, 2014.

[31] I. Sologuren, S. Boisson-Dupuis, J. Pestano et al., "Partial recessive IFN- $\gamma$ R1 deficiency: genetic, immunological and clinical features of 14 patients from 11 kindreds," Human Molecular Genetics, vol. 20, no. 8, pp. 1509-1523, 2011.

[32] P. Remiszewski, B. Roszkowska-Sliz, J. Winek et al., "Disseminated Mycobacterium avium infection in a 20-year-old female with partial recessive IFN $\gamma \mathrm{R} 1$ deficiency," Respiration, vol. 73, no. 3, pp. 375-378, 2006.

[33] J. G. Shin, B. L. Park, L. H. Kim et al., “Association study of polymorphisms in interferon- $\gamma$ receptor genes with the risk of pulmonary tuberculosis," Molecular Medicine Reports, vol. 12, no. 1, pp. 1568-1578, 2015.
[34] A. A. Velayati, P. Farnia, S. Khalizadeh, A. M. Farahbod, M. Hasanzadh, and M. F. Sheikolslam, "Interferon-gamma receptor-1 gene promoter polymorphisms and susceptibility to leprosy in children of a single family," The American Journal of Tropical Medicine and Hygiene, vol. 84, no. 4, pp. 627-629, 2011.

[35] P. Farnia, J. Ghanavi, S. Saif, P. Farnia, and A. A. Velayati, "Association of interferon- $\gamma$ receptor-1 gene polymorphism with nontuberculous mycobacterial lung infection among Iranian patients with pulmonary disease," The American Journal of Tropical Medicine and Hygiene, vol. 97, no. 1, pp. 57-61, 2017.

[36] L. Bulat-Kardum, G. E. Etokebe, J. Knezevic et al., "Interferon$\gamma$ receptor-1 gene promoter polymorphisms (G-611A; T-56C) and susceptibility to tuberculosis," Scandinavian Journal of Immunology, vol. 63, no. 2, pp. 142-150, 2006.

[37] S. D. Rosenzweig, A. A. Schaffer, L. Ding et al., "Interferon- $\gamma$ receptor 1 promoter polymorphisms: population distribution and functional implications," Clinical Immunology, vol. 112, no. 1, pp. 113-119, 2004.

[38] W. Wang, W. Ren, X. Zhang, Y. Liu, and C. Li, “Association between interferon gamma receptor $1-56 \mathrm{C} / \mathrm{T}$ gene polymorphism and tuberculosis susceptibility: a meta-analysis," Chinese Medical Journal, vol. 127, no. 21, pp. 3782-3788, 2014. 


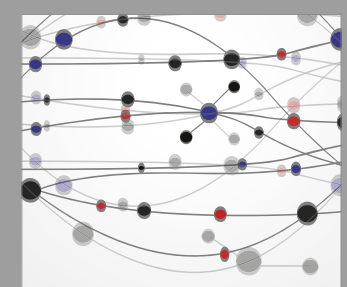

The Scientific World Journal
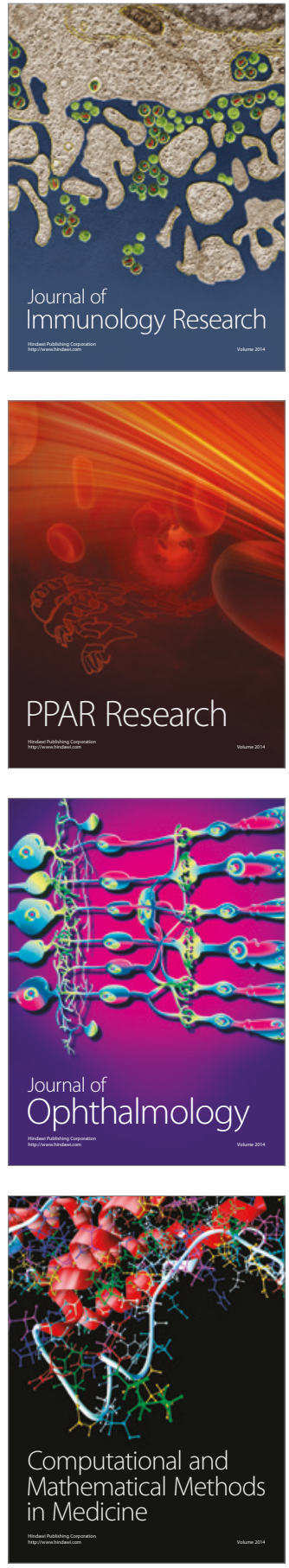

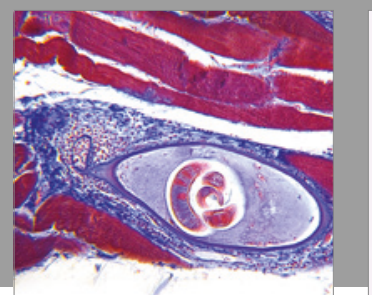

Gastroenterology Research and Practice
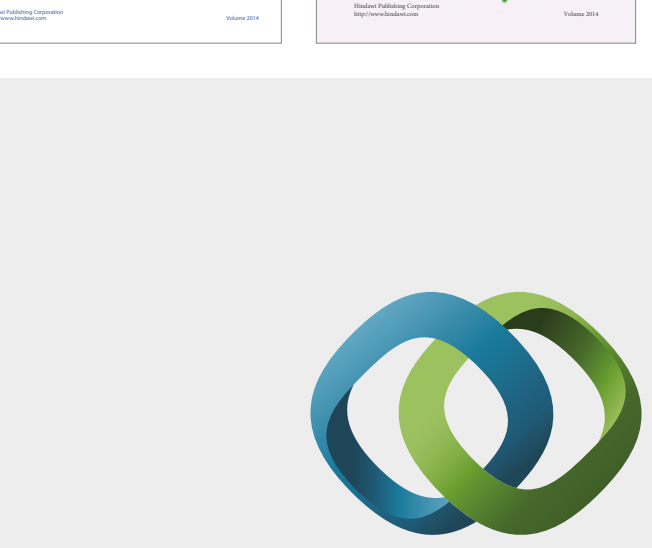

\section{Hindawi}

Submit your manuscripts at

https://www.hindawi.com
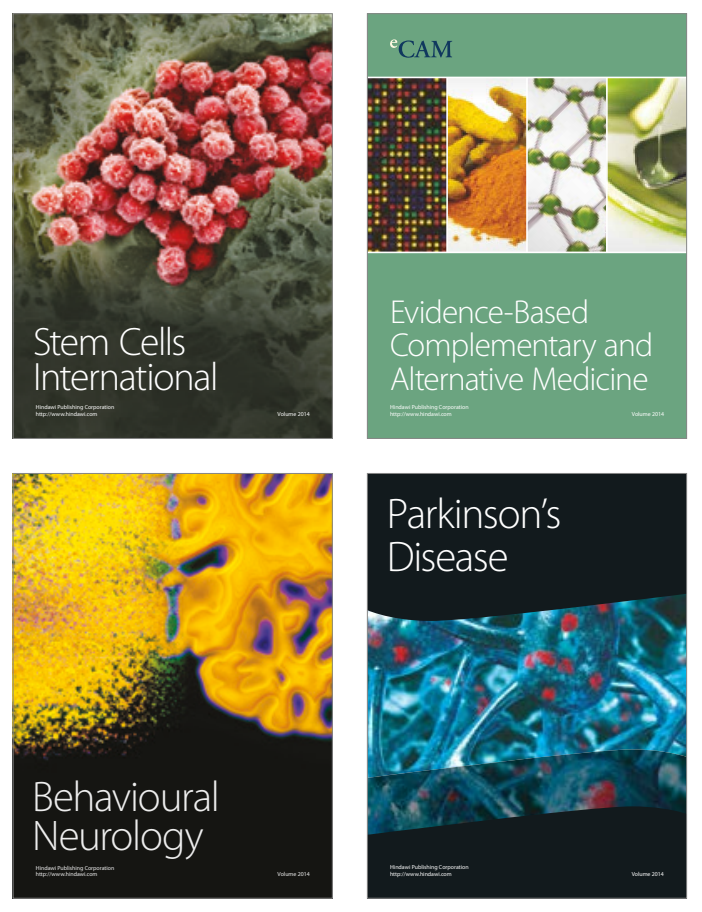
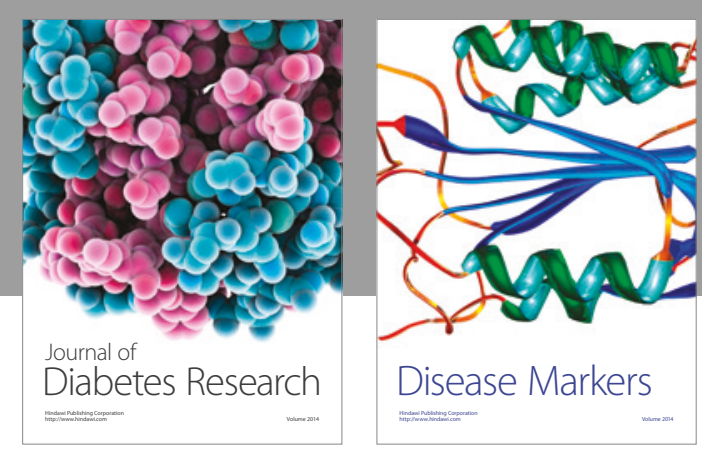

Disease Markers
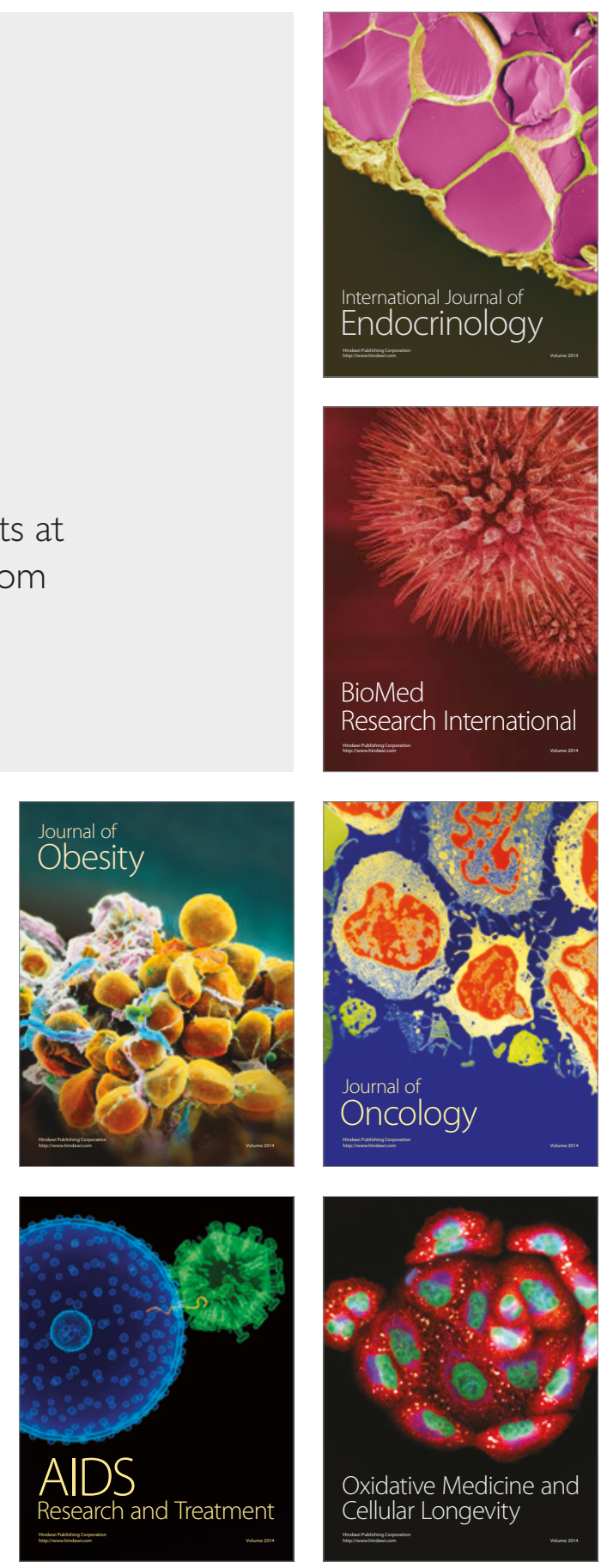